\title{
Expression in Escherichia coli of flaB, the gene coding for a periplasmic flagellin of Leptospira interrogans serovar pomona
}

\author{
MIN LIN, NASREEN BUGHIO and OM SURUJBALLI \\ Animal Diseases Research Institute, Nepean, Ontario, Canada K2H 8P9
}

\begin{abstract}
A periplasmic flagellin gene, flaB, of Leptospira interrogans serovar pomona (strain Pomona) was expressed in Escherichia coli for the production and antigenic characterisation of the protein. The $f l a B$ structural gene, which was previously cloned into pUC118, was derived by PCR from the recombinant plasmid and used to generate an expression construct with the trc promoter-driven pProEx HT system. Under the conditions employed, the $f a B$ was expressed as inclusion bodies formed within $E$. coli, yielding c. $120 \mathrm{mg}$ of the recombinant protein/L of culture. A polyhistidine tag introduced at the amino-acid terminus of the FlaB protein allowed for the purification of the protein by nickel-chelate affinity chromatography. The expressed protein reacted with both mouse and bovine antisera to $L$. interrogans on Western blots, indicating that it could be of use in the diagnosis of leptospirosis. The recombinant leptospiral flagellin may also be of value in studying its role in the pathogenesis of leptospirosis.
\end{abstract}

\section{Introduction}

Leptospirosis is a zoonosis caused by pathogenic serovars within the genus Leptospira. It is a spirochaetal disease of both animals and man, causing abortion, stillbirth, infertility, decreased milk production, and sometimes death in domestic livestock [1]. Infection in man is not common except in tropical regions and occurs mostly through occupational or accidental contact with infected animals or through the ingestion of water contaminated with their urine $[2,3]$. The control of leptospirosis relies on serological identification of infected animals with crude or purified antigens, or both, exhibiting a varying degree of diagnostic sensitivity. Leptospiral antigens (proteins, carbohydrates, lipids) are isolated from whole organisms or fractions thereof [4-10]. Such procedures present a potential health hazard in handling infectious live organisms, the difficulty of producing a large quantity of leptospires and a complication in purifying the antigens to homogeneity. Recombinant DNA technology offers an alternative approach to overcome such problems encountered during the preparation of leptospiral antigens for diagnostic purposes.

Pathogenic leptospires, previously classified as one

Received 3 Sept. 1998; revised version received 20 Nov. 1998; accepted 4 March 1999.

Corresponding author: Dr M. Lin. species (Leptospira interrogans), are now subdivided into seven species: $L$. borgpetersenii, $L$. inadai, $L$. interrogans, L. kirschneri, L. noguchii, L. santarosai and $L$. weilii, on the basis of DNA relatedness $[11,12]$ and DNA polymorphic patterns [13]. These species comprise $>200$ serovars that are grouped into 23 serogroups [14]. Leptospire motility is mediated by two periplasmic flagella (PF) located within the periplasmic space, between the outer membrane sheath and the helically shaped cytoplasmic cylinder [15]. The PF is composed of a basal body, hook and filament [16]. The filaments from spirochaetes [17-24] comprise two distinct classes of proteins, FlaA and $\mathrm{FlaB}$, that are present in the outer sheath and core layers of the PF filament, respectively. Monoclonal and polyclonal antibodies have been used recently to identify a strong immunoreactive protein of $35 \mathrm{kDa}$ in L. interrogans serovar pomona (strain Pomona), which was shown by $\mathrm{N}$-terminal sequencing and gene cloning to be the FlaB protein [25].

A structural role has been proposed for the $\mathrm{N}$-terminal and C-terminal regions of a flagellin, i.e., they point into the interior of the filament to form a hairpin loop structure with exposure of the central part on the outer surface of the filament $[26,27]$. The terminal regions are also believed to be involved in filament assembly [28-30]. Comparison of the serovar pomona FlaB with flagellins from various bacterial species showed that the central region is the most variable in amino-acid 
sequence [25]. In contrast, the FlaB proteins are highly conserved among the pathogenic Leptospira serovars and do not appear to contain serovar-specific determinants in the central regions of the proteins [31]. According to the structural model proposed by Homma et al. [26] and Namba et al. [27], it has been suggested that the variable central region exposed on the outer surface of the filament is involved in the induction of a species-specific immune response in an infected host $[25,32]$. Thus, expression of a flaB gene in a heterologous host will provide a valuable protein material in large amounts for evaluation of its diagnostic potential, study of its roles in pathogenesis and immunity, and elucidation of its structure and function. An earlier study cloned and sequenced the $f l a B$ gene of strain Pomona [25]. In the present, a gene construct was generated with a pProEx HT vector to express the pomona $f a B$ in Escherichia coli. Purification and antigenic characterisation of the recombinant FlaB protein are reported as a part of the initial investigation aimed at the application of this protein as an immunological reagent in the detection of leptospiral infection.

\section{Materials and methods}

\section{Chemicals, vectors and bacterial strains}

Isopropyl- $\beta$-D-thiogalactoside (IPTG), phenylmethylsulphonyl fluoride (PMSF) and ampicillin were purchased from Sigma. Taq DNA polymerase, protein expression vectors (pProEx HT) and $E$. coli DH5 $\alpha$ competent cells were obtained from Life Technologies (Burlington, Ontario, Canada). Deep Vent DNA polymerase, restriction endonucleases, the $\mathrm{M} 13 / \mathrm{pUC}$ reverse primer (5'AGCGGATAACAATTTCACACAGG3') and other molecular biology reagents were purchased from New England Biolabs (Mississauga, Ontario, Canada). Nickel-nitrilotriacetic acid (Ni-NTA) agarose and monoclonal anti-histidine tag antibody (anti-His MAb) were supplied by Qiagen (Santa Clarita, CA, USA). All other chemicals were of commercially available analytical grade.

\section{Construction of expression vector}

All DNA manipulations were performed according to established procedures [33]. The $f a B$ gene was derived by PCR from pUC118pomFla-1 [25] with a thermostable DNA polymerase mixture of Taq and Deep Vent as described previously [31] with the primers (5' ACAGGATCCATGATTATCAATCACAACCT3' and 5'GTGGAGCTCTCAGATGTGCTGCAGAAGCTT3', which have the Bam HI or SacI restriction sites incorporated at their $5^{\prime}$ ends (underlined). The PCRamplified $f a B$ gene was inserted as a sticky-ended fragment into the Bam HI and SacI cloning sites of pProEx HT. The recombinant plasmid thus constructed, designated pHTFlaB, was used to transform the expression host $E$. coli strain $\mathrm{DH} 5 \alpha$ to ampicillin resistance. The presence of an insert in recombinant plasmids was confirmed by double digests with Bam HI/SacI. The pHTFlaB was sequenced as previously described [25] with the $\mathrm{M} 13 / \mathrm{pUC}$ reverse primer (5'AGCGGATAACAATTTCACACAGG3') to ensure that the $f l a B$ gene was in-frame at the fusion point.

\section{SDS-PAGE and Western blotting}

SDS-PAGE was performed by the method of Laemmli [34] with stacking 4\% gels and resolving $12 \%$ gels in a mini-gel apparatus (BioRad, Mississauga, Ontario, Canada) [35]. The separated proteins were either stained with Coomassie Blue or analysed by Western blots [35] probed with mouse or bovine polyclonal antisera to $L$. interrogans. Immunostaining was done with an alkaline phosphatase or horseradish peroxidase substrate kit (BioRad).

\section{Expression of the flaB gene in E. coli}

The cells harbouring pHTFlaB were cultured at $37^{\circ} \mathrm{C}$ in $10 \mathrm{ml}$ of Luria-Bertani broth supplemented with ampicillin $100 \mu \mathrm{g} / \mathrm{ml}$. After growth to an $\mathrm{A}_{595}$ of between 0.6 and 1.0, the culture was induced to express the recombinant protein by addition of $0.6 \mathrm{mM}$ IPTG. The level of protein expression was monitored over a time course of $3 \mathrm{~h}$ by SDS-PAGE. For routine purification of the recombinant FlaB protein, a 500$\mathrm{ml}$ culture was grown. After induction with IPTG for $2 \mathrm{~h}$, cells were harvested by centrifugation at $10000 \mathrm{~g}$ for $20 \mathrm{~min}$. The cell pellets were stored frozen $\left(-80^{\circ} \mathrm{C}\right)$ until used.

\section{Analysis of solubility of the expressed protein}

The IPTG-induced cell pellets (c. $2 \mathrm{~g}$ fresh weight) were resuspended in $10 \mathrm{ml}$ of phosphate-buffered saline (PBS) containing $1 \mathrm{mM}$ PMSF and passed through a French press cell at $14000 \mathrm{psi}$. The homogenate was collected and centrifuged at $27000 \mathrm{~g}$ for $30 \mathrm{~min}$. The whole cell extract, supernate and insoluble fractions (pellets) were analysed by SDS-PAGE for the presence of the expressed protein.

\section{Purification of the recombinant FlaB protein}

The buffers used in protein purification were buffer A (8 $\mathrm{M}$ urea, $0.1 \mathrm{M} \mathrm{Na}_{2} \mathrm{HPO}_{4}, 1 \mathrm{mM} \mathrm{PMSF}$ and $0.01 \mathrm{M}$ Tris- $\mathrm{HCl}, \mathrm{pH} 8.0$ ), buffer $\mathrm{B}$ (8 $\mathrm{M}$ urea, $0.1 \mathrm{M} \mathrm{Na}_{2} \mathrm{HPO}_{4}$, $1 \mathrm{M} \mathrm{NaCl}$ and $0.01 \mathrm{M}$ Tris- $\mathrm{HCl}, \mathrm{pH} 6.3$ ) and buffer $\mathrm{C}$ $\left(8 \mathrm{M}\right.$ urea, $0.1 \mathrm{M} \mathrm{Na}_{2} \mathrm{HPO}_{4}, 1 \mathrm{M} \mathrm{NaCl}$ and $0.01 \mathrm{M}$ Tris$\mathrm{HCl}, \mathrm{pH} \mathrm{5.9)}$.

Frozen cells (c. $2 \mathrm{~g}$ fresh weight) were resuspended in $10 \mathrm{ml}$ of buffer A with stirring at room temperature for $1 \mathrm{~h}$ and then at $4^{\circ} \mathrm{C}$ overnight. The cell extract was centrifuged at $30900 \mathrm{~g}$ for $40 \mathrm{~min}$. The supernate was collected and loaded, at $0.5 \mathrm{ml} / \mathrm{min}$, on to a Ni-NTA 
agarose column $(1 \times 7.5 \mathrm{~cm})$ that had been preequilibrated with buffer $A$. The column was serially washed with $40 \mathrm{ml}$ of buffer A, $40 \mathrm{ml}$ of buffer B and $40 \mathrm{ml}$ of buffer $\mathrm{C}$. Proteins were eluted from the column with $80 \mathrm{mM}$ imidazole in buffer C. Fractions $(2 \mathrm{ml})$ were collected and the absorbance was monitored at $280 \mathrm{~nm}$. Peak fractions were pooled and stored at $-20^{\circ} \mathrm{C}$. The protein concentration was determined by the method of Bradford [36], with bovine serum albumin as the standard reference protein.

\section{Protein N-terminal amino-acid sequencing}

The affinity-purified recombinant protein preparation was separated by SDS-PAGE and electroblotted on to a polyvinylidene difluoride membrane. Protein N-terminal amino-acid sequence was determined by Edman degradation with a Model 470A gas-phase sequencer equipped with an on-line model 120A PTH analyser (Applied Biosystems, Foster City, CA, USA).

\section{Results and discussion}

\section{Expression of $L$. interrogans flaB gene}

PCR amplification of pUC118pomFla-1 [25] gave a product of $870 \mathrm{bp}$, comprising the $f l a B$ structural gene and a restriction endonuclease recognition sequence at each end to allow cloning into the vector, pProEx HT; this plasmid contains the $l a c \mathrm{I}^{\mathrm{q}}$ gene, thereby enabling IPTG-induced expression of the inserted gene from the trc promoter. By inserting the $f a B$ structural gene downstream in frame with the initiation codon of a coding sequence for MSYYHHHHHHDYDIPTTENLYFQGAMGS - underlined are a six-histidine tag and a Tobacco Etch Virus (TEV) protease cleavage site, respectively - an expression vector (designated pHTFlaB) producing a FlaB fusion protein with a polyhistidine tag at the N-terminus was constructed. The histidine tag facilitates affinity purification of the desired protein and may be removed by proteolysis with TEV protease.

Expression of the L. interrogans flaB gene in E. coli was followed for $3 \mathrm{~h}$ by SDS-PAGE after the addition of IPTG (Fig. 1). Upon induction, a strong protein band of $c .31 \mathrm{kDa}$ was seen; this was slightly smaller than the predicted size of the FlaB fusion protein $(34.686 \mathrm{kDa})$. This protein was detected on Western blots probed with anti-His MAb (data not shown). The non-induced cells containing pHTFlaB (Fig. 1, lane 2) and the non-induced or induced cells harbouring pProEx HT (not shown in Fig. 1) showed no protein band in this region. Therefore, these results indicated expression of the recombinant protein. Differences between the apparent and deduced molecular masses of proteins have been generally recognised; possibly molecular mass estimation with SDS-PAGE is not precise. Maximal expression of the recombinant protein was seen after induction for $2 \mathrm{~h}$ (Fig. 1, lane 4). To

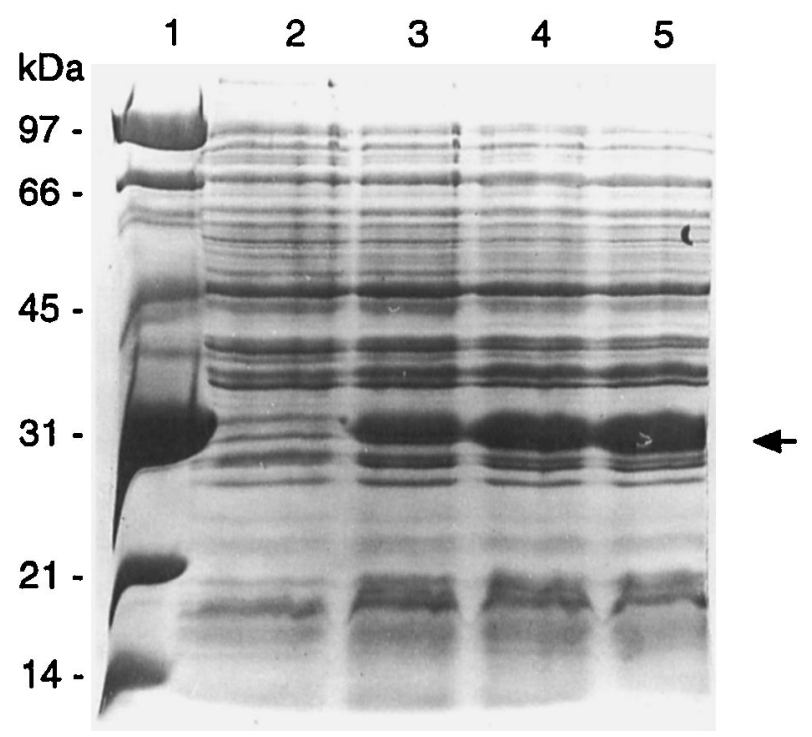

Fig. 1. Expression of the $L$. interrogans $f a B$ gene in $E$. coli. The cells harbouring $\mathrm{pHTFlaB}$, following induction with $0.6 \mathrm{mM}$ IPTG, were analysed by SDS-PAGE $(12 \%)$ for presence of the recombinant FlaB in a 3-h experiment. The cells were lysed with the SDS/ $\beta$-mercaptoethanol sample buffer and heated at $100^{\circ} \mathrm{C}$ for $5 \mathrm{~min}$ before loading on to the gel. Lane 1, molecular mass standards; 2, proteins from non-induced cells; 3-5, proteins from induced cells (1, 2 and $3 \mathrm{~h}$, respectively). Each lane contains total cell proteins from $1 \mathrm{ml}$ of culture with an $\mathrm{A}_{590}$ of 0.2 . The induced recombinant protein is indicated $(\leftarrow)$.

determine whether FlaB was expressed as a soluble or insoluble protein, cells were disrupted with a French press and both soluble fraction and pellets were analysed by SDS-PAGE. The expressed protein was not seen in the culture supernate (Fig. 2, lane 1) or in the soluble cellular fraction (lane 4), but was present in the insoluble fraction (lane 3 ). This suggested that the recombinant protein had formed inclusion bodies within the the cytoplasm of E. coli.

\section{Purification and antigenic characterisation of the recombinant FlaB protein}

Because it was expressed in an insoluble form within E. coli, the recombinant FlaB was purified under denaturing conditions. The recombinant protein, extracted and solubilised from the cells with urea, was purified by affinity chromatography on a Ni-NTA agarose column. SDS-PAGE analysis of the final preparation of the recombinant protein showed a purity of $>95 \%$ (Fig. 3). The purified $31-\mathrm{kDa}$ protein was analysed by $\mathrm{N}$-terminal amino-acid sequencing, which confirmed it as the FlaB fusion protein. An additional minor protein band of $35-\mathrm{kDa}$ was present in the FlaB fusion protein preparation (Fig. 3, lane 5). This copurifying $35-\mathrm{kDa}$ protein is believed to be a partially denatured form of the FlaB fusion protein because it reacted with a mouse polyclonal antiserum to $L$. interrogans (Fig. 4a, lane 2). Assuming 100\% recovery of the FlaB protein from affinity chromatography and 


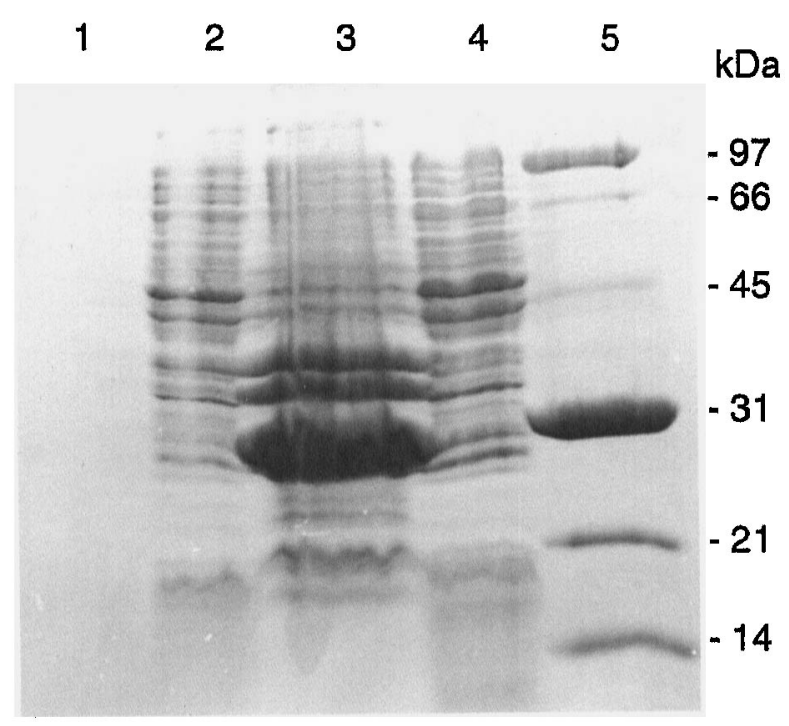

Fig. 2. Analysis of solubility of the recombinant $L$. interrogans $\mathrm{FlaB}$ protein expressed in E. coli. The sample was prepared as described in Materials and methods. Cells containing pHTFlaB were induced with IPTG for $2 \mathrm{~h}$, disrupted with a French press, and analysed by SDS-PAGE (12\%) for soluble and insoluble proteins. Lane 1 , culture supernate; 2 , proteins from noninduced cells; 3 , proteins from the insoluble fraction; 4 , proteins from the soluble fraction; 5, molecular mass standards.

95\% purity in the final FlaB preparation, it was estimated that expression of the $f a B$ gene in $E$. coli yielded c. $120 \mathrm{mg}$ of the recombinant protein $/ \mathrm{L}$ of cell culture. Thus, the expression construct pHTFlaB, in combination with one-step affinity chromatography, resulted in a large quantity of purified recombinant FlaB protein. The recombinant leptospiral flagellin may be of value in developing a recombinant protein-based serodiagnostic test and in studying its roles in pathogenesis and immunity.

The serovar pomona FlaB was previously shown to react with a specific mouse $\mathrm{MAb}$ and antisera from leptospire-infected cattle [25]. To evaluate the antigenicity of the expressed FlaB protein, whole cell extract prepared from the IPTG-induced cells harbouring pHTFlaB was analysed by Western blots which were probed with mouse polyclonal antiserum directed against strain Pomona. As shown in Fig. 4a (lane 2), mouse antiserum detected a protein band of $31 \mathrm{kDa}$, which was previously confirmed to be the recombinant FlaB fusion protein by Western blots with anti-His $\mathrm{MAb}$ and by $\mathrm{N}$-terminal amino-acid sequencing. The affinity-purified recombinant protein was further analysed by Western blotting with field sera from cattle infected (13 animals) or not infected with (12 animals) with $L$. interrogans. The antisera from all infected animals used were capable of recognising the recombinant FlaB, whereas the sera from non-infected animals did not show specific immunological reaction with the protein. Fig. $4 \mathrm{~b}$ illustrates representative results for four infected (lanes 1-4) and four non-infected (lanes 5-8) animals. It may also be noted that an ELISA with the purified protein immobilised on the plate gave results consistent with the Western blotting data. All these results indicate that the recombinant protein is immunologically active and is similar in antigenicity to the native protein. Thus, the recombinant FlaB may be a useful reagent for the serological detection of infection with pathogenic leptospires, particularly in an ELISA format.

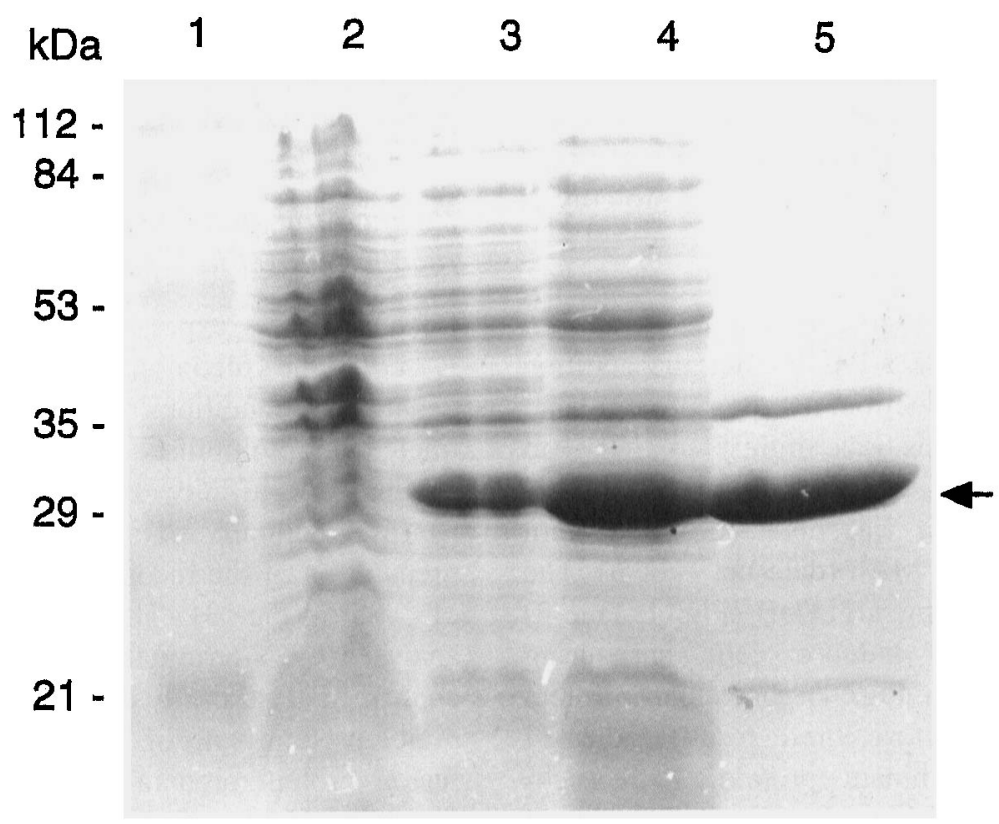

Fig. 3. SDS-PAGE analysis of the recombinant $L$. interrogans FlaB fusion protein purified from $E$. coli by affinity chromatography on a Ni-NTA agarose column. Lane 1, molecular mass standards; 2, whole cell proteins from noninduced cells; 3, whole cell proteins from IPTG-induced cells; 4, urea-extracted proteins from IPTG-induced cells; 5, affinity-purified FlaB preparation. The recombinant protein is indicated $(\leftarrow)$. 
a

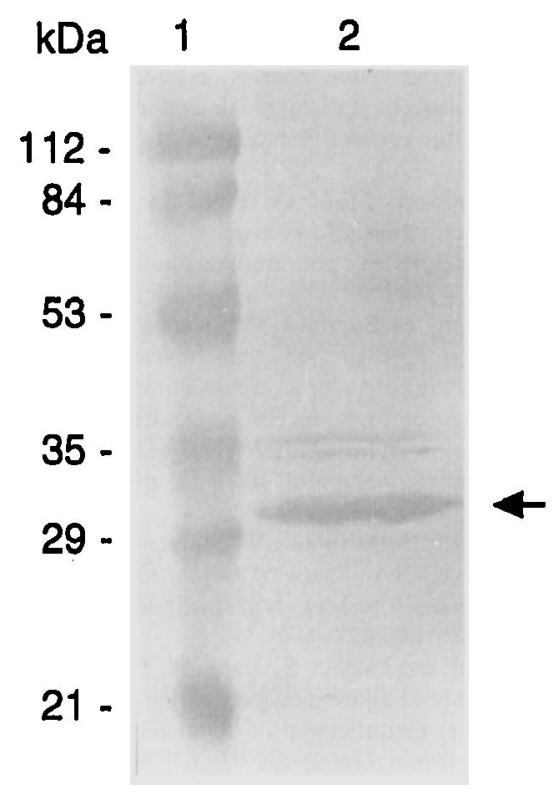

b

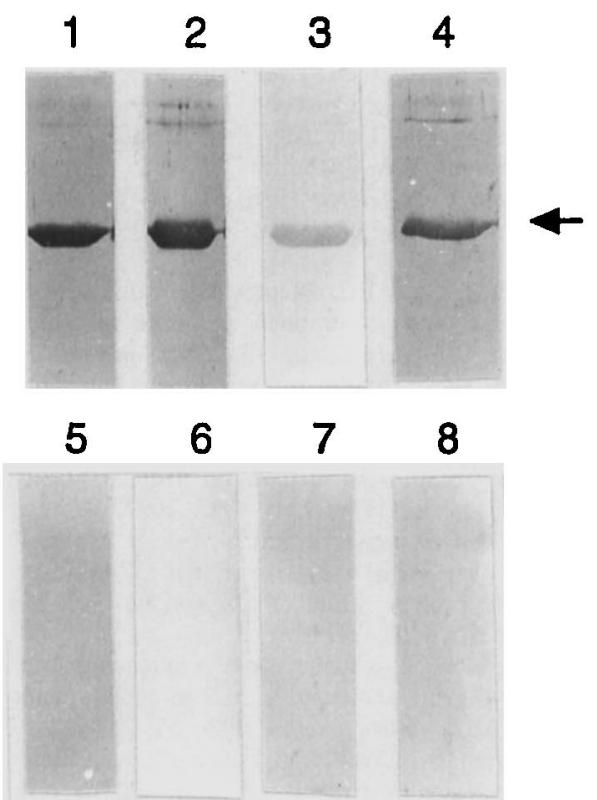

Fig. 4. (a) Detection of the recombinant $L$. interrogans FlaB protein expressed in E. coli by Western blots probed with mouse polyclonal antiserum ( 1 in 1000 dilution) to L. interrogans serovar pomona (strain Pomona). Lane 1, molecular mass standards; 2, whole cell proteins from IPTG-induced cells containing pHTFlaB. (b) Western blot analysis of the recombinant $\mathrm{FlaB}$ of $L$. interrogans serovar pomona with field sera from $L$. interrogans-infected or non-infected cattle. The affinity-purified FlaB was immobilised on nitrocellulose membranes and probed with sera from four infected (lanes 1-4) and four non-infected (5-8) cattle at a dilution of 1 in 1000. The recombinant protein is indicated $(\leftarrow)$.

Spirochaetal gene expression studies have mostly centred on Borrelia burgdorferi [32,37-42] and Treponema pallidum [21,43-49], and there have been limited studies on leptospires. For example, Yamaguchi et al. [50] and Doherty et al. [51] demonstrated the expression in $E$. coli of leptospiral antigen genes by using specific antisera on colony immunoblots, although the sequence identity of these genes was not determined. More recent studies on the expression of genes of pathogenic Leptospira spp., including those coding for surface proteins OmpL1 and LipL41 $[52,53]$ and a periplasmic flagellin of serovar grippotyphosa [24], have been reported. The present study has extended the previous work by showing another example of expression in $E$. coli of a leptospiral antigen gene, i.e., the serovar pomona $f l a B$, and by reporting purification and antigenic characterisation of the recombinant product.

In summary, an expression construct, pHTFlaB, has been generated for effective production of a leptospiral flagellin protein (FlaB), in E. coli. Antigenic characterisation of the recombinant protein indicates that it may have value in the serodiagnisis of leptospirosis.

We thank Drs G. Randall, K. Nielsen and F. Thomas for stimulating discussion and suggestions; Drs C. Lutze-Wallace and S. Nadin-Davis for critical review of the manuscript; A. Bergern for determination of DNA sequences; and D. C. Watson for determination of N-terminal amino acid sequences. N. B. was supported by a post-doctoral fellowship from a Canadian Government Matching Investment Initiative grant through the Natural Sciences and Engineering
Research Council of Canada. This work was supported in part by Diachemix Corporation (USA).

\section{References}

1. Thiermann AB. Leptospirosis: current developments and trends. J Am Vet Med Assoc 1984; 184: 722-725.

2. Heath SE, Johnson R. Leptospirosis. J Am Vet Med Assoc 1994; 205: $1518-1523$.

3. Farr RW. Leptospirosis. Clin Infect Dis 1995; 21: 1-8.

4. Chang A, Faine S. Electron-microscopic evidence for reactions of axial filaments of Leptospira with $\mathrm{IgM}$ and $\mathrm{IgG}$ antibodies. Bull World Health Organ 1970; 43: 571-577.

5. Palit A, Gulasekharam J. Genus-specific leptospiral antigen and its possible use in laboratory diagnosis. J Clin Pathol 1973; 26: $7-16$.

6. Myers DM, Coltorti EA. Broadly reacting precipitating and agglutinating antigen of Leptospirae. J Clin Microbiol 1978; 8: $580-590$.

7. Chapman AJ, Adler B, Faine S. Genus-specific antigens in leptospira revealed by immunoblotting. Zentralbl Bakteriol Mikrobiol Hyg A 1987; 264: 279-293.

8. Srivastava SK, Verma R, Gupta BR. Characterization of protein antigens of Leptospira interrogans serovar pomona. Indian $J$ Animal Sci 1989; 59: 328-334.

9. Ballard SA, Faine S, Adler B. Purification and characterization of a protein antigen from Leptospira interrogans serovar hardjo, common to a wide range of bacteria. $J$ Gen Microbiol 1990; 136: 1849-1857.

10. Brown JA, LeFebvre RB, Pan MJ. Protein and antigen profiles of prevalent serovars of Leptospira interrogans. Infect Immun 1991; 59: 1772-1777.

11. Yasuda PH, Steigerwalt AG, Sulzer KR, Kaufmann AF, Rogers $F$, Brenner DJ. Deoxyribonucleic acid relatedness between serogroups and serovars in the family Leptospiraceae with proposals for seven new Leptospira species. Int $J$ Syst Bacteriol 1987; 37: 407-415.

12. Ramadass P, Jarvis BDW, Corner RJ, Penny D, Marshall RB. Genetic characterization of pathogenic Leptospira species by 
DNA hybridization. Int $J$ Syst Bacteriol 1992; 42: 215-219.

13. Ralph D, McClelland M, Welsh J, Baranton G, Perolat P. Leptospira species categorized by arbitrarily primed polymerase chain reaction and by mapped restriction polymorphisms in PCR-amplified rRNA genes. J Bacteriol 1993; 175: 973-981.

14. Kmety E, Dikken H. Revised list of Leptospira serovars. Groningen, The Netherlands, University Press. 1988.

15. Goldstein SF, Charon NW. Motility of the spirochete Leptospira. Cell Motil Cytoskeleton 1988; 9: 101-110.

16. Smibert RM. Spirochaetales, a review. Crit Rev Microbio 1973; 2: $491-552$.

17. Norris SJ, Charon NW, Cook RG, Fuentes MD, Limberger RJ. Antigenic relatedness and N-terminal sequence homology define two classes of periplasmic flagellar proteins of Treponema pallidum subsp. pallidum and Treponema phagedenis. J Bacteriol 1988; 170: 4072-4082.

18. Brahamsha B, Greenberg EP. Cloning and sequence analysis of flaA, a gene encoding a Spirochaeta aurantia flagellar filament surface antigen. J Bacteriol 1989; 171: 1692-1697.

19. Isaacs RD, Hanke JH, Guzman-Verduzco L-M et al. Molecular cloning and DNA sequence analysis of the 37-kilodalton endoflagellar sheath protein gene of Treponema pallidum. Infect Immun 1989; 57: 3403-3411.

20. Pallesen L, Hindersson P. Cloning and sequencing of Treponema pallidum gene encoding a 31.3-kilodalton endoflagellar subunit (FlaB2). Infect Immun 1989; 57: 2166-2172.

21. Champion CI, Miller JN, Lovett MA, Blanco DR. Cloning, sequencing and expression of two class B endoflagellar genes of Treponema pallidum subsp. pallidum encoding the 34.5-and 31.0-kilodalton proteins. Infect Immun 1990; 58: 1697-1704.

22. Mitchison M, Rood JI, Faine S, Adler B. Molecular analysis of a Leptospira borgpetersenii gene encoding an endoflagellar subunit protein. J Gen Microbiol 1991; 137: 1529-1536.

23. Parales J, Greenberg EP. N-terminal amino acid sequences and amino acid compositions of the Spirochaeta aurantia flagellar filament polypeptides. J Bacteriol 1991; 173: 1357-1359.

24. Woodward MJ, Redstone JS. Deoxynucleotide sequence conservation of the endoflagellin subunit protein gene, $\mathrm{flaB}$, within the genus Leptospira. Vet Microbiol 1994; 40: 239-251.

25. Lin M, Surujballi O, Nielsen K, Nadin-Davis S, Randall G Identification of a 35-kilodalton serovar-cross-reactive flagellar protein, FlaB, from Leptospira interrogans by $\mathrm{N}$-terminal sequencing, gene cloning, and sequence analysis. Infect Immun 1997; 65: 4355-4359.

26. Homma M, Fujita H, Yamaguchi S, Iino T. Regions of Salmonella typhimurium flagellin essential for its polymerisation and excretion. J Bacteriol 1987; 169: 291-296.

27. Namba K, Yamashita I, Vonderviszt F. Structure of the core and central channel of bacterial flagella. Nature 1989; 342. 648-654.

28. Joys TM. The covalent structure of the phase-1 flagellar filament protein of Salmonella typhimurium and its comparison with other flagellins. $J$ Biol Chem 1985; 260: $15758-15761$.

29. Wei L-N, Joys TM. Covalent structure of three phase-1 flagellar filament proteins of Salmonella. $J$ Mol Biol 1985; 186: $791-803$

30. Trachtenberg S, DeRosier DJ. Three-dimensional reconstruction of the flagellar filament of Caulobacter crescentus. A flagellin lacking the outer domain and its amino acid sequence lacking an internal segment. $J \mathrm{Mol}$ Biol 1988; 202: 787-808.

31. Lin M. Molecular analysis of $f a B$, a periplasmic flagellar core protein gene in pathogenic leptospires. $J$ Biochem $\mathrm{Mol}$ Biol Biophys 1999; 2: 181-187.

32. Wallich R, Moter SE, Simon MM, Ebnet K, Heiberger A Kramer MD. The Borrelia burgdorferi flagellum-associated 41kilodalton antigen (flagellin): molecular cloning, expression, and amplification of the gene. Infect Immun 1990; 58: 1711-1719.

33. Sambrook J, Fritsch EF, Maniatis T. Molecular cloning: a laboratory manual; 2nd edn. Cold Spring Harbor, Cold Spring Habor Laboratory Press. 1989.
34. Laemmli UK. Cleavage of structural proteins during the assembly of the head of bacteriophage T4. Nature 1970; 227: $680-685$.

35. Lin M, Sugden EA, Jolley ME, Stilwell K. Modification of the Mycobacterium bovis extracellular protein MPB70 with fluorescein for rapid detection of specific serum antibodies by fluorescence polarization. Clin Diagn Lab Immunol 1996; 3 : 438-443.

36. Bradford MM. A rapid and sensitive method for the quantitation of microgram quantities of protein utilizing the principle of protein-dye binding. Anal Biochem 1976; 72 248-254.

37. Fikrig E, Barthold SW, Kantor FS, Flavell RA. Protection of mice against the Lyme disease agent by immunizing with recombinant OspA. Science 1990; 250: 553-556.

38. Gassmann GS, Jacobs E, Deutzmann R, Göbel UB. Analysis of the Borrelia burgdorferi $\mathrm{GeHo} f l a$ gene and antigenic characterization of its gene product. J Bacteriol 1991; 173: 1452-1459.

39. Fikrig E, Barthold SW, Marcantonio N, Deponte K, Kantor FS, Flavell RA. Roles of OspA, OspB, and flagellin in protective immunity to lyme borreliosis in laboratory mice. Infect Immun 1992; 60: 657-661.

40. Luft BJ, Pawagi S, Jiang W, Fiseene S, Gorevic PD, Dunn J. Analysis and expression of the Borrelia burgdorferi $\mathrm{P} / \mathrm{Gau}$ fla gene: identification of heterogeneity with the B31 strain. FEMS Microbiol Lett 1992; 93: 63-68.

41. Jauris-Heipke S, Fuchs R, Motz M et al. Genetic heterogenity of the genes coding for the outer surface protein $\mathrm{C}(\mathrm{OspC})$ and the flagellin of Borrelia burgdorferi. Med Microbiol Immunol 1993; 182: $37-50$.

42. Ge Y, Charon NW. FlaA, a putative flagellar outer sheath protein, is not an immunodominant antigen associated with Lyme disease. Infect Immun 1997; 65: 2992-2995.

43. Stamm LV, Folds JD, Bassford PJ. Expression of Treponema pallidum antigens in Escherichia coli K-12. Infect Immun 1982; 36: $1238-1241$.

44. Walfield AM, Hanff PA, Lovett MA. Expression of Treponema pallidum antigens in Escherichia coli. Science 1982; 216: $522-523$.

45. Norgard MV, Miller JN. Cloning and expression of Treponema pallidum (Nichols) antigen genes in Escherichia coli. Infect Immun 1983; 42: 435-445.

46. van Embden JD, ven der Donk HJ, van Eijk RV et al. Molecular cloning and expression of Treponema pallidum DNA in Escherichia coli K-12. Infect Immun 1983; 42: 187-196.

47. Norgard MV, Chamberlain NR, Swancutt MA, Goldberg MS Cloning and expression of the major 47-kilodalton surface immunogen of Treponema pallidum in Escherichia coli. Infect Immun 1986; 54: 500-506.

48. Isaacs RD, Radolf JD. Expression in Escherichia coli of the 37-kilodalton endoflagellar sheath protein of Treponema pallidum by use of the polymerase chain reaction and a $\mathrm{T} 7$ expression system. Infect Immun 1990; 58: 2025-2034.

49. Blanco DR, Champion CI, Exner MM et al. Recombinant Treponema pallidum rare outer membrane protein 1 (Tromp 1) expressed in Escherichia coli has porin activity and surface antigenic exposure. $J$ Bacteriol 1996; 178: 6685-6692.

50. Yamaguchi T, Ono E, Yanagawa R. Expression of antigen genes of Leptospira interrogans serovar canicola in Escherichia coli. Microbiol Immunol 1988; 32: 1179-1187.

51. Doherty JP, Adler B, Rood JI, Billington SJ, Faine S Expression of two conserved leptospiral antigens in Escher ichia coli. J Med Microbiol 1989; 28: 143-149.

52. Shang ES, Exner MM, Summers TA et al. The rare outer membrane protein, OmpL1, of pathogenic Leptospira species is a heat-modifiable porin. Infect Immun 1995; 63: 3174-3181.

53. Shang ES, Summers TA, Haake DA. Molecular cloning and sequence analysis of the gene encoding LipL41, a surfaceexposed lipoprotein of pathogenic Leptospira species. Infect Immun 1996; 64: 2322-2330. 